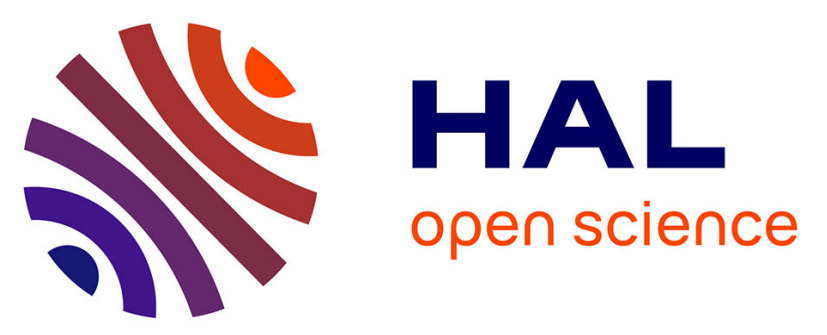

\title{
Molecular characterization of genetic diversity within the Africa/Middle East/Asia Minor and Sub-Saharan African groups of the Bemisia tabaci species complex
}

Hélène Henri, Gabriel Terraz, Olivier Gnankine, Frédéric Fleury, Laurence

Mouton

\section{To cite this version:}

Hélène Henri, Gabriel Terraz, Olivier Gnankine, Frédéric Fleury, Laurence Mouton. Molecular characterization of genetic diversity within the Africa/Middle East/Asia Minor and Sub-Saharan African groups of the Bemisia tabaci species complex. International Journal of Pest Management, 2013, 59 (4), pp.329 - 338. 10.1080/09670874.2013.869374 . hal-01971410

\author{
HAL Id: hal-01971410 \\ https://hal.science/hal-01971410
}

Submitted on 7 Jan 2019

HAL is a multi-disciplinary open access archive for the deposit and dissemination of scientific research documents, whether they are published or not. The documents may come from teaching and research institutions in France or abroad, or from public or private research centers.
L'archive ouverte pluridisciplinaire HAL, est destinée au dépôt et à la diffusion de documents scientifiques de niveau recherche, publiés ou non, émanant des établissements d'enseignement et de recherche français ou étrangers, des laboratoires publics ou privés. 
Hélène Henri ${ }^{1}$, Gabriel Terraz ${ }^{1}$, Olivier Gnankiné ${ }^{2}$, Frédéric Fleury ${ }^{1}$ \& Laurence Mouton ${ }^{1}$

6
${ }^{1}$ Université de Lyon, Université Lyon1, Laboratoire de Biométrie et Biologie Evolutive, UMR CNRS 5558, 43 Bd du 11 Novembre 1918, 69622 Villeurbanne Cedex, France

${ }^{2}$ Université de Ouagadougou, Unité de Formation et de Recherche en Sciences de la Vie et de la Terre (UFR-SVT), Laboratoire d'Entomologie Fondamentale et Appliquée, 09848 Ouagadougou 09, Burkina Faso

\section{Corresponding author}

L. Mouton

Université de Lyon, Université Lyon1, Laboratoire de Biométrie et Biologie Evolutive, UMR CNRS 5558, 43 Bd du 11 Novembre 1918, 69622 Villeurbanne Cedex, France.

Tel ++33(0)4 72432910

Fax: ++33(0)4 78892719

E-mail: laurence.mouton@univ-lyon1.fr

Running title: PCR-RFLP for detecting B. tabaci diversity 
Abstract

Bemisia tabaci Gennadius is a major plant pest in many agricultural systems worldwide. It is a complex of cryptic species that differ in many ecological respects, including damagecausing potential. Monitoring the genetic composition of B. tabaci populations in the field is, therefore, essential for achieving effective control. Sequencing is costly and time-consuming, thus, efficient diagnostic tools must be developed to perform epidemiological studies involving hundreds of individuals. Here, we describe a PCR-RFLP method for identifying all the putative species comprising the Africa/Middle East/Asia Minor group, including those that are the most devastating crop pests. Moreover, intra-specific diversity associated with specific symbiotic bacteria known to manipulate insect host phenotypes can also be detected. Additionally, this method discriminates between the Africa/Middle East/Asia Minor and the Sub-Saharan African groups, which are sympatric in some areas. This simple, reliable and cost-effective diagnostic tool is ideal for the rapid analysis of a high number of individuals and, thus, has potential applications in field contexts, where it could provide valuable baseline information for pest management programs.

Keywords: PCR-RFLP, Bemisia tabaci, mtCOI gene, molecular diagnostic, Sub-Saharan Africa group, MEAM1 species, Mediterranean species, pest management program. 


\section{Introduction}

The whitefly Bemisia tabaci Gennadius is one of the most important pests worldwide, causing significant damage to food and ornamental crops directly by feeding on sap and, to an even greater extent, indirectly by transmitting many plant-pathogenic viruses (Jones 2003). B. tabaci displays considerable genetic and biological variability despite its morphological homogeneity, which has led to the conclusion that it is in fact a complex of morphologically indistinguishable 'cryptic' species (Perring 2001; De Barro et al. 2011). The genetic complexity of $B$. tabaci has mainly been investigated using mitochondrial cytochrome oxidase gene (mtCO1) sequence data (Frohlich et al. 1999; Boykin et al. 2007). This has led to the identification of several genetic groups known as biotypes, but the use of the term 'biotype' is now subjected to debate. The taxonomy and systematics of $B$. tabaci have not yet been completely elucidated, but recently it was proposed that a value of $3.5 \% \mathrm{mtCO}$ sequence divergence should be used to distinguish 28 putative cryptic species within the $B$. tabaci complex (Dinsdale et al. 2010; Hu et al. 2011; see De Barro et al. 2011 and Liu et al. 2012 for review). Those species fall into 11 major groups (> 11\% divergence), which include those previously described as biotypes. In this study, we have adopted the nomenclature proposed by Dinsdale et al. (2010), but we have also included the biotype designation so as to make it easier to relate our study to the previously published literature. Among the 28 putative species, two stand out as being the most predominant and devastating worldwide, the Middle East - Asia Minor species 1 (commonly known as biotype B; referred to hereafter as MEAM1) and the Mediterranean MED species (which includes the Q, J, L and ASL biotypes). These two species belong to the same Africa/Middle East/Asia Minor major group of B. tabaci identified by Dinsdale et al. (2010), which also includes MEAM2 and Indian Ocean IO species (formerly known as the MS biotype). The MED and 
MEAM1 species have colonized large areas of most continents as a result of introduction/invasion processes (Bedford et al. 1994; Liu et al. 2007; De Barro and Ahmed 2011). Their invasive ability is mainly attributable to their having a broad spectrum of host plants, better reproductive and competitive potential, and greater insecticide resistance. In the Mediterranean basin, the MED species predominates. In some areas, it coexists locally with MEAM1. The MED species is common in North Africa, and has spread, probably recently, into West Central Africa and South Africa, where it coexists with the Sub-Saharan Africa indigenous species (also known as the AnSL biotypes; referred to hereafter as SSAF species) (Gueguen et al. 2010; Esterhuizen et al. 2013).

The MED species appears to be genetically diverse not only because it includes the Q, J, L, and Sub-Saharan Africa Silverleaf ASL biotypes (De Barro et al. 2011), but also because high genetic variability has been observed within the Q group, leading to the recognition of several cytotypes on the basis of $m t C O 1$ gene sequencing and symbiotic bacterial infection (Gueguen et al. 2010; Chu et al. 2012). Chu et al. (2012) recognized five subclades, designated as Q1Q5, four of which correspond to the previously known Q1, Q2, Q3 and ASL genetic groups (Gueguen et al. 2010). These genetic groups display some particular features. First, they have different geographical and host plant ranges. For example, Q1 and Q2 have been sampled at a large geographical scale on a wide spectrum of host plants, whereas Q3 has only been observed in Western Africa on Lantana camara and tobacco (Gnankiné et al. 2012). The Q subclades also differ with regard to the composition of the bacterial symbiotic communities they harbor (Gueguen et al. 2010; Gnankiné et al. 2012). Some of these bacteria are known to induce drastic phenotypic change in $B$. tabaci, conferring features such as a fitness benefit (Kontseladov et al. 2008; Himler et al. 2011). Finally, they also differ as regards the 
93 frequencies of alleles resistant to pyrethroids and organo-phosphates (Mouton et al. al. 2012; Esterhuizen et al. 2013). unpublished data).

The spread of the MED and MEAM1 species worldwide has had a considerable impact on agriculture (for review, see Oetting and Buntin 1996), and many studies have focused on identifying the mechanisms underlying their invasiveness and the best methods of control. This requires monitoring B.tabaci populations to track the evolution of the species composition in the invaded areas. Gene sequencing is costly and time-consuming, therefore, other effective diagnostic tools need to be developed in order to perform epidemiological studies involving hundreds of individuals. One of the various PCR-based methods, PCRRFLP, consists of digestion with restriction enzymes after a polymerase chain reaction, and it provides a simple, fast and effective way to detect some of the variations in DNA sequences without sequencing. This technique has already been developed for use in $B$. tabaci, mainly to distinguish MEAM1, MED and non-MEAM1, non-MED species (Bosco et al. 2006; Tsagkarakou et al. 2007; Vassiliou et al. 2008; Ma et al. 2009; Shatters et al. 2009). Moreover, other PCR-RFLP protocols have been proposed to detect genetic variability in the Mediterranean basin, but these do not identify all the genetic diversity known to exist in the Africa/Middle East/Asia Minor group (Sartor et al. 2008; Chu et al. 2012). In this study, we describe a PCR-RFLP method that can be used to identify all the putative species that belong to the major groups (MED, MEAM1, MEAM2, Indian Ocean IO species), and also to recognize within-species variations. We also considered the Sub-Saharan Africa group, which is composed of several Sub-Saharan African species (SSAF1-5 species), which are sympatric with the MED species in some localities (Berry et al. 2004; Gueguen et al. 2010; Gnankiné et 


\subsection{Phylogenetic analyses}

120 We performed a phylogenetic analysis to determine the genetic diversity within $B$. tabaci

121 populations in the two major groups under consideration in this study, i.e., the Africa/Middle

122 East/Asia Minor and the Sub-Saharan Africa clades. All the mtCOI sequences of B. tabaci available in Genbank for these two groups were analyzed, and only the sequences of around $657 \mathrm{bp}$ with no undefined nucleotides, and no gaps or indels, were used. This gave us 143 sequences originating from samples collected worldwide (Table 1). Multiple sequence 126 alignment was carried out using MUSCLE software (Edgar 2004) implemented in CLC DNA

127 Workbench (CLC bio). Only non-redundant sequences were retained to construct the tree; this gave us 25 haplotypes (for each haplotype, the sequence used for the analysis is shown in bold type in Table 1). Phylogenetic analyses were performed using maximum likelihood and

130 Bayesian inferences. The appropriate model of evolution selected with jModeltest v0.1.1

131 (Posada 2008) was $G T R+I+G$ for both methods. ML analyses were performed with Phyml v

1323.0 (100 bootstrap replicates) (Guindon et al. 2010). Bayesian analyses were done using

133 MrBayes v 3.1.2 with 500,000 generations (Ronquist and Huelsenbeck 2003). Results were 134 plotted using Figtree v1.3.1.

\subsection{In-silico selection of restriction enzymes}

137 Restriction enzymes were selected by in silico analyses of the 25 haplotypes using the CLC 138 DNA Workbench 6.0 (CLC Bio) program. CLC sequence viewer was used to predict 139 restrictions sites on a 657-bp fragment of the mtCOI gene sequence with 50 restriction 140 enzymes. 


\subsection{PCR-RFLP on field samples}

143 The PCR-RFLP tool developed in this study was tested on almost 1,100 B. tabaci individuals

144 originating from France, Spain, Israel, Greece, Togo, Benin and Burkina Faso, and collected

145 from various host plants (Table 2). DNA was extracted using the procedure of Gueguen et al.

146 (2010). Briefly, individual insects were ground in $25 \mu \mathrm{L}$ of extraction buffer containing 50

$147 \mathrm{mM} \mathrm{KCl}, 10 \mathrm{mM}$ Tris-base $\mathrm{pH} 8.0,0.45 \%$ Nonidet P-40, 0.45\% Tween 20 and $500 \mathrm{mg} / \mathrm{mL}$

148 proteinase K. Samples were incubated at $65^{\circ} \mathrm{C}$ for $3 \mathrm{~h}$ and then at $100{ }^{\circ} \mathrm{C}$ for $15 \mathrm{~min}$. A 35 -

$149 \mu \mathrm{L}$ aliquot of pure water was added to this extract, which was then stored at $-20{ }^{\circ} \mathrm{C}$ until use.

150 An 819-bp fragment of $m t C O I$ was amplified with the primers C1-J-2195 and L2-N-3014

151 (Simon et al. 1994). PCR amplifications were performed in a final volume of $25 \mu \mathrm{L}$

152 containing $200 \mu \mathrm{M}$ dNTPs, $200 \mathrm{nM}$ of each primer, $1.5 \mathrm{mM}$ of $\mathrm{MgCl}_{2}$, $0.5 \mathrm{U}$ of Taq

153 polymerase (EuroblueTaq, Eurobio, France) and $2 \mu \mathrm{L}$ of DNA template. The cycling profile

154 consisted of an initial denaturing phase at $95{ }^{\circ} \mathrm{C}$ for $2 \mathrm{~min}$, followed by 35 cycles consisting

155 of: $94{ }^{\circ} \mathrm{C}$ for $1 \mathrm{~min}$ (denaturing), $50{ }^{\circ} \mathrm{C}$ for $1 \mathrm{~min}$ (annealing) and $72{ }^{\circ} \mathrm{C}$ for $1 \mathrm{~min}$

156 (extension) followed by a final extension phase at $72{ }^{\circ} \mathrm{C}$ for $10 \mathrm{~min}$. PCR products $(10 \mu \mathrm{L})$

157 were digested with XapI, and another $10 \mu \mathrm{L}$ was digested with $\mathrm{BfmI}(10 \mathrm{UI})$ at $37{ }^{\circ} \mathrm{C}$ for $3 \mathrm{~h}$.

158 The products obtained were then separated by electrophoresis on a $2 \%$ agarose gel at $100 \mathrm{~V}$

159 for $1 \mathrm{~h}$ and visualized by ethidium bromide staining. In parallel, PCR products were directly

160 sequenced from 120 individuals. 


\subsection{Phylogenetic structure}

165 The phylogenetic tree obtained with the 25 selected haplotypes is consistent with the most

166 recent B. tabaci phylogenies available in the literature (Dinsdale et al. 2010; De Barro et al.

167 2011). Since the ML and the Bayesian analyses led to substantially the same topology, we 168 present only the ML analysis (Fig. 1). Genetic variability was observed within the major 169 groups and species recognized by De Barro et al. (2011). Fifteen haplotypes were identified in 170 the Africa/Middle East/Asia Minor group, and seven in the Sub-Saharan Africa group. 171 Genetic diversity was also found within species, with up to nine haplotypes in the MED 172 species and four in MEAM1. Polymorphism was lower in the other species analyzed (five 173 haplotypes for SSAF5, three for SSAF1, two for SSAF2 and one for MEAM2, IO, SSAF3 and SSAF4), but this may have been due to the limited number of sequences available in

175 Genbank for these species.

\subsection{In silico PCR-RFLP}

178 Two restriction enzymes were selected after in-silico analysis on the basis of their capacity to 179 discriminate between the Africa/Middle East/Asia Minor and Sub-Saharan Africa major 180 groups, and their ability to discriminate within these groups between the putative species 181 described by Dinsdale et al. (2010) and De Barro et al. (2011). Ten and nine profile types 182 were found for XapI and BfmI, respectively (Fig. 2). Both enzymes were able reliably to 183 distinguish between the two major groups. For XapI, we found profile types \#1, 2, 5, 8, 9 and

18410 for the Africa/Middle East/Asia Minor group, and profile types \#3, 4, 6 and 7 for the Sub185 Saharan Africa major group. For $B f m I$, profiles \#1, 2, 4, 5, 6, 8, 9 correspond to the 
186 Africa/Middle East/Asia Minor group, while profiles \#3 and 7 characterized the Sub-Saharan

187 Africa major group (Fig. 1, Table 1). Seventeen profiles were obtained when simultaneous 188 DNA digestion by both enzymes was performed: 12 for the Africa/Middle East/Asia Minor 189 group and 7 for the Sub-Saharan Africa group (Table 1). Within the Sub-Saharan Africa 190 group, we were unable to distinguish all the SSAF species. In contrast, within the

191 Africa/Middle East/Asia Minor group, PCR-RFLP profiles distinguished all the putative species: profiles 1, 2 and 3 were particular to the MEAM1 species; profiles 5 to 11 were specific to the MED species, and profiles 4 and 12 characterized the MEAM2 and IO species,

194 respectively. In summary, in-silico analysis suggests that XapI and BfmI acting 195 simultaneously offer good potential identification of all four putative species in the 196 Africa/Middle East/Asia Minor group, including the ability to detect within-species diversity, since 12 profiles were obtained for 15 known haplotypes.

\subsection{PCR-RFLP on field samples}

200 The in-silico predictions were checked on field samples belonging to the Africa/Middle 201 East/Asia Minor (MEAM1 and MED species) and the Sub-Saharan Africa (SSAF1 and SSAF2 species) groups. We performed both PCR-RFLP and $m t C O I$ gene sequencing on 120 B. tabaci individuals collected worldwide from several plants (Table 2). For another 959

204 individuals, the identification was done using the PCR-RFLP method only, in order to check 205 the reliability of the method. Digestion with XapI and $B f m I$ generated six and four distinct 206 restriction patterns in our samples, respectively, differing by the number and/or size of the 207 fragments, making it possible to identify the MEAM1, MED and SSAF species (Fig. 3) as 208 predicted by the in-silico analysis (Table 1). Moreover, restriction profiles differentiated 209 haplotypes within the MED species, making it possible to recognize the commonly known 
210 ASL, Q1, Q2, Q3 genetic groups previously described as different biotypes or cytotypes, 211 which harbor different bacterial endosymbionts. Fragments of less than 50 bp were not 212 detected, because they were too small to be visualized by electrophoresis in a routine agarose 213 gel assay. Moreover, the size of the bands observed for some restriction profiles deviated 214 slightly from predictions; this was because the in-silico analysis was performed on $657 \mathrm{bp}$, 215 which is only a part of the 867-bp amplicon obtained with the primers used to amplify the 216 mtCOI gene in B. tabaci (C1-J-2195 and L2-N-3014; Simon et al. 1994).

217 For all 120 individuals in which biotype identification was carried out using both standard $218 m t C O I$ gene sequencing and PCR-RFLP assay, the same results were obtained by both 219 methods (Table 2). Moreover, we did not detect any unexpected restriction profiles for the 220959 other individuals screened by PCR-RFLP only. This implies there was no other sequence 221 variation at the XapI and BfmI restriction sites than those detected by the in silico analysis. 
225 In this paper a simple diagnostic tool, based on a PCR-RFLP method on the mtCO1 gene was 226 used:

1) To reliably distinguish between the two major groups of $B$. tabaci that coexist in sympatry in some places in the Mediterranean basin and Africa (Gueguen et al. 2010; Gnankiné et al. 2012; Esterhuizen et al. 2013): the Africa/Middle East/Asia Minor group, which includes the two most invasive members (B and Q biotypes), and the Sub-Saharan Africa group, which is regarded as the basal clade of B. tabaci.

2) To detect all the putative species defined in the Africa/Middle East/Asia Minor group by De Barro et al. (2011) and Dinsdale et al. (2010). These species include MEAM1 (formerly referred to as biotype B) and MED (biotype Q), which are widespread and considered to be

237 the ones that cause the most damage (Oetting and Buntin 1996). In many places, displacement 238 of MEAM1 by MED has been observed (Horowitz et al. 2005; Crowder et al. 2010), and the 239 mechanism(s) underlying this phenomenon have been investigated for many years; this 240 requires monitoring $B$. tabaci populations to track the evolution of the species composition in 241 these areas. One explanation for this displacement could be the fact that these two species 242 differ in their susceptibility towards various insecticides. Indeed, it has been demonstrated 243 that the use of neonicotinoids or pyriproxyfen positively selects for the MED species, which 244 exhibits greater resistance to these insecticides than the MEAM1 species (Horowitz et al. 245 2005). 
Genetic diversity at the mitochondrial level has also been detected at a finer scale, i.e., within species. This PCR-RFLP protocol makes it possible to identify entities previously recognized as the Q1, Q2, Q3 and ASL genetic groups on the basis of $m t C O 1$ gene sequencing. While it is still not completely clear whether these groups are of any biological significance, some arguments suggest that this distinction should be taken into account. First, these haplotypes harbour particular symbiont communities that can potentially modify a number of biological traits in their host (Chiel et al. 2007; Gueguen et al. 2010; Gnankine et al. 2012). Second, all the genetic groups of MED species are structured geographically (Gueguen et al. 2010; Gnankiné et al. 2012), so that tracking them provides a way of identifying the invasion routes of $B$. tabaci. Lastly, they are associated with biological 256 features, such as host plant use (Gnankiné et al. 2012), and the frequency of insecticideresistant alleles (Mouton et al., unpublished data). This further suggests that the mitochondrial diversity could also be associated with nuclear variation and possible genetic isolation. This last point is important because species definition by Dinsdale et al. (2010) is based on $m t C O I$ 260 divergence, which means that some so-far unidentified, genetically isolated entities may exist 261 at a finer phylogenetic scale. In a recent study, Chu et al. (2012) found five haplotypes within the MED species by $m t C O 1$ sequencing. However, the PCR-RFLP method they developed for 263 the $m t C O I$ gene using the restriction enzyme VspI only distinguished one haplotype, which 264 corresponds to the commonly known Q1 biotype, but the method was unable to detect the 265 other four. The tool we developed here can be used to identify four out of the five $m t C O I$ 266 haplotypes described in the MED species. It can thus detect diversity at a very fine scale, 267 which may make it very useful in population studies and may have major implications for pest management programs. 
269 Levels of resistance and resistance mutation frequencies to insecticides differ between $B$. 270 tabaci species (Horowitz et al. 2005; Wang et al. 2010; Alon et al. 2006, 2008) but also 271 within species as has been observed within the MED species (Mouton pers. com.) Therefore, 272 to be effective, strategies developed to control this pest must differ according to the local $B$. 273 tabaci composition and the chemical classes of insecticides used. Monitoring the evolution of 274 genetic diversity is, thus, clearly required for effective control strategies of this pest. The tool 275 developed here has already been successfully used for describing the diversity of $B$. tabaci 276 genetic groups in western Africa (Gnankiné et al. 2012; Gnankiné et al. 2013; Mouton, pers. 277 com.) and could be useful to monitor the dynamics of B. tabaci populations in relation to 278 insecticide resistance in countries, like west African countries, where insecticides are widely 279 used and lead to high levels of resistance (Houndété et al. 2010). 
284 This study was partially funded by CNRS (IFR41-UMR5558) and by the Agence 285 Universitaire de la Francophonie (AUF). Gabriel Terraz is the recipient of a Ph.D. studentship 286 from the Rhône-Alpes region ("Program Cible" Grant). The authors would like to thank A. 287 Tsagkarakou, J. Arno, G. Bout and E. Zchori-Fein, who supplied us with samples, and F. 288 Vavre for helpful discussion and comments. 
291 Alon M, Alon F, Nauen R, Morin S. 2008. Organophosphates' resistance in the B-biotype of 292 Bemisia tabaci (Hemiptera: Aleyrodidae) is associated with a point mutation in an ace1-type 293 acetylcholinesterase and overexpression of carboxylesterase. Insect Biochem Mol Biol 38: $294940-949$.

295 Alon M, Benting J, Lueke B, Ponge T, Alon F, Morin S. 2006. Multiple origins of pyrethroid 296 resistance in sympatric biotypes of Bemisia tabaci (Hemiptera: Aleyrodidae). Insect Biochem Mol Biol 36: 71-79.

Bedford ID, Briddon RW, Brown JK, Rosell RC, Markham PG. 1994. Geminivirus transmission and biological characterisation of Bemisia tabaci (Gennadius) biotypes from different geographic regions. Ann Appl Biol 125: 311-325.

Berry SD, Fondong VN, Rey MEC, Rogan D, Fauquet C., Brown JK. 2004. Molecular evidence for five distinct Bemisia tabaci (Homoptera; Aleyrodidae) geographic haplotypes associated with cassava plants in sub-Saharan Africa. Ann Entomol Soc Am 97: 852-859.

Bosco D, Loria A, Sartor C, Cenis JL. 2006. PCR-RFLP Identification of Bemisia tabaci biotypes in the Mediterranean Basin. Phytoparasitica 34: 243-251.

Boykin LM, Shatters RG, Rosell RC, McKenzie CL, Bagnall RA, De Barro P, Frohlich DR. 307 2007. Global relationships of Bemisia tabaci (Hemiptera: Aleyrodidae) revealed using 308 Bayesian analysis of mitochondrial COI DNA sequences. Mol Phyl Evol 44: 1306-1319.

309 Chiel E, Gottlieb Y, Zchori-Fein E, Mozes-Daube N, Katzir N, Inbar M, Ghanim M. 2007. 310 Biotype-dependent secondary symbiont communities in sympatric populations of Bemisia 311 tabaci. Bull Entomol Res 97: 407-413.

312 Chu D, Hu X, Gao C, Zhao H, Nichols RL, Li X. 2012. Use of mitochondrial cytochrome 313 oxidase I polymerase chain reaction-restriction fragment length polymorphism for 
314 identifying subclades of Bemisia tabaci Mediterranean group. J Econ Entomol 105: 242251.

316 Crowder DW, Horowitz R, De Barro PJ, Liu SS, Showalter AM, Kontsedalov S, Khasdan V,

317 Shargal A, Liu J, Carriere Y. 2010. Mating behaviour, life history and adaptation to 318 insecticides determine species exclusion between whiteflies. J Anim Ecol 79: 563-570.

319 De Barro P, Ahmed M. 2011. Genetic networking of the Bemisia tabaci cryptic species $320 \quad$ complex reveals pattern of biological invasions. PLoS ONE 6: e25579.

321 De Barro PJ, Liu SS, Boykin LM, Dinsdale B. 2011. Bemisia tabaci: a statement of species 322 status. Ann Rev Entomol 56: 1-19.

323 Dinsdale A, Cook L, Riginos C, Buckley YM, De Barro P. 2010. Refined global analysis of 324 Bemisia tabaci (Hemiptera: Sternorrhyncha: Aleyrodoidae: Aleyrodidae) mitochondrial cytochrome oxidase 1 to identify species level genetic boundaries. Ann Entomol Soc Am 103: $196-208$

Edgar RC. 2004. MUSCLE: a multiple sequence alignment method with reduced time and space complexity. BMC Bioinformatics 5: 113.

329 Esterhuizen LL, Mabasa KG, van Heerden SW, Czosnek H, Brown JK, van Heerden H, Rey 330 MEC. 2013. Genetic identification of members of the Bemisia tabaci cryptic species 331 complex from South Africa reveals native and introduced haplotypes. J Appl Entomol 137: $122-135$.

Frohlich DR, Torres-Jerez I, Bedford ID, Markham PG, Brown JK. 1999. A 334 phylogeographical analysis of the Bemisia tabaci species complex based on mitochondrial DNA markers. Mol Ecol 8: 1683-1691.

336 Gnankiné O*, Mouton L*, Henri H, Terraz G, Houndeté T, Martin T, Vavre F, Fleury F. 2012. Distribution of the Bemisia tabaci biotypes (Homoptera: Aleyrodidae) and their 
associated symbiotic bacteria on host plants in Western Africa. $\left(* 1^{\text {st }}\right.$ co-authors). Insect Cons Div, DOI: 10.1111/j.1752-4598.2012.00206.x

340 Gnankiné O, Mouton L, Savadogo A, Martin T, Sanon A, Vavre F, Fleury F. 2013. Biotype

341 status and resistance to neonicotinoid and carbosulfan in Bemisia tabaci (Hemiptera:

342 Aleyrodidae) in Burkina Faso, West Africa. Int $\mathrm{J}$ Pest Manage, DOI:

$343 \quad 10.1080 / 09670874.2013 .771806$.

344 Gueguen G, Vavre F, Gnankine O, Peterschmitt M, Charif D, Chiel E, Gottlieb Y, Ghanim M,

345 Zchori-Fein E, Fleury F. 2010. Endosymbiont metacommunities, mtDNA diversity and the 346 evolution of the Bemisia tabaci (Hemiptera: Aleyrodidae) species complex. Mol Ecol 19:

$347 \quad 4365-4378$.

348 Guindon S, Dufayard J-F, Lefort V, Anisimova M, Hordijk W, Gascuel O. 2010. New 349 algorithms and methods to estimate maximum-likelihood phylogenies: assessing the 350 performance of PhyML 3.0. System Biol 59: 307-321.

351 Horowitz AR, Kontsedalov S, Khasdan V, Ishaaya I. 2005. Biotypes B and Q of Bemisia 352 tabaci and their relevance to neonicotinoid and pyriproxyfen resistance. Arch Insect 353 Biochem Physiol 58: 216-225.

354 Houndété TA, Kétoh GK, Hema OSA, Brévaukt T, Glitho IA, Martin T. 2010. Insecticide 355 resistance in field populations of Bemisia tabaci (Hemiptera: Aleyrodidae) in West Africa. 356 Pest Manag Sci 11: 1181-1185.

357 Hu J, De Barro P, Zhao H, Wang J, Nardi F, Liu S-S. 2011. An extensive field survey 358 combined with a phylogenetic analysis reveals rapid and widespread invasion of two alien 359 whiteflies in China. Plos One 6: e16061.

360 Jones DR. 2003. Plant viruses transmitted by whiteflies. Eur J Plant Pathol 109: 195-219. 
Liu SS, Colvin J, De Barro PJ. 2012. Species concepts as applied to the whitefly Bemisia tabaci systematics: how many species are there? J Int Agr 11: 176-186.

Liu SS, De Barro PJ, Xu J, Luan JB, Zang LS, Ruan YM, Wan FH. 2007. Asymmetric mating interactions drive widespread invasion and displacement in a whitefly. Science 318: 17691772.

Ma W-H, Li X-C, Lei C-L, Wang M, Degain BA, Nichols RL. 2009. Utility of mtCOI 367 polymerase chain reaction-restriction fragment length polymorphism in differentiating between Q and B whitefly Bemisia tabaci biotypes. Insect Sci 16: 107-114.

Oetting RD, Buntin GD. 1996. Bemisia damage expression in commercial greenhouse production. In: Gerling, D., Mayer, R.T. (Eds.), Bemisia: 1995 Taxonomy, Biology, Damage, Control and Management. Intercept, UK, pp. 201-208.

Perring TM. 2001. The Bemisia tabaci species complex. Crop Prot 20: 725-737.

Posada D. 2008. jModelTest: phylogenetic model averaging. Mol Biol Evol 25: 1253-1256.

Ronquist F, Huelsenbeck JP. 2003. MrBayes 3: Bayesian phylogenetic inference under mixed models. Bioinformatics 19: 1572-1574.

Sartor C, Demichelis S, Cenis JL, Coulibaly AK, Bosco D. 2008. Genetic variability of Bemisia tabaci in the Mediterranean and Sahel regions. Bull Insect 61: 161-162. barcoding method for Bemisia tabaci and related Aleyrodidae: development of universal and Bemisia tabaci biotype-specific mitochondrial cytochrome c oxidase I polymerase chain reaction primers. J Econ Entomol 102: 750-758.

Simon C, Frati F, Beckenbach A, Crespi B, Liu H, Flook P. 1994. Evolution, weighting, and phylogenetic utility of mitochondrial gene sequences and a compilation of conserved PCR primers. Ann Entomol Soc Am 87: 651-701. 
385 Tsagkarakou A, Tsigenopoulos CS, Gorman K, Lagnel J, Bedford ID. 2007. Biotype status 386 and genetic polymorphism of the whitefly Bemisia tabaci (Hemiptera: Aleyrodidae) in 387 Greece: mitochondrial DNA and microsatellites. Bull Entomol Res 97: 29-40.

388 Vassiliou VA, Jagge C, Grispou M, Pietrantonio PV, Tsagkarakou A. 2008. Biotype status of 389 Bemisia tabaci from various crops in Cyprus. Phytoparasiticia 36: 400-404.

390 Wang Z, Yan H, Yang Y, Wu Y. 2010. Biotype and insecticide resistance status of the 391 whitefly Bemisia tabaci from China. Pest Manag Sci 66: 1360-1366.

392 
394 Figure 1: $m t$ COI gene-based phylogeny of the Africa/Middle East/Asia Minor and Sub395 Saharan Africa major groups of B. tabaci using maximum likelihood (ML) analyses.

396 Bootstrap values are shown at the nodes for ML analysis, followed by the corresponding 397 posterior probabilities obtained by Bayesian inferences. Sequences were retrieved from 398 Genbank. Bemisia afer was used as the outgroup. The analysis was based on a 657-bp 399 sequence. Biotypes and access numbers are indicated at each branch, as is the type of profile 400 obtained with each enzyme (XapI/BfmI). Frames indicate the specific profiles that can be used 401 to distinguish between the sequences (for example, profiles \#10 and \#2 obtained with XapI 402 are specific to the MEAM1 species, whereas restriction with both enzymes is required to 403 identify Q1, Q2, Q3, and L2).

404

405 Figure 2: $I n$-silico restriction profiles obtained with XapI (A) and BfmI (B). The sizes of the 406 bands corresponding to the ladder are indicated (bp).

407

408 Figure 3: PCR-RFLP assays with XapI (A) and BfmI (B).

409 The sizes of the different bands obtained, and the sizes (bp) of the bands corresponding to the 410 ladder are indicated on the left and the right of the figure, respectively. 